\title{
KARAKTERISTIK DAN MOTIVASI WISATAWAN EKOWISATA DI BALI (STUDI KASUS DI JARINGAN EKOWISATA DESA)
}

\author{
Wiwin Roy Jaya Saragih \\ I Made Sendra \\ I GPB. Sasrawan Mananda \\ Email :win_roy@yahoo.com \\ PS. S1 Industri Perjalanan Wisata \\ Fakultas Pariwisata UNUD
}

\begin{abstract}
This study discusses about tourist characteristic and motivation in Pelaga, Badung Regency, Sibetan, Karangasem Regency, and Tenganan, Karangasem Regency. These three villages were developed into ecotourism village by JED (Village Ecotourism Network). Ecotourism is a communitybased tourism, enviromentally sound, and responsible for sustainability. By seeing the number of visitor in Pelaga Ecotourism Village which has yet to reach the target, this is the impact of marketing system is still very common conducted without regard to the characteristics and motivations of tourists. This research purposes is to know the tourist characteristic and motivation who visit Pelaga, Sibetan, and Tenganan Ecotourism Village.

Data collection in this research is done by direct obeservation to Pelaga Village, Sibetan Village, and Tenganan Village. Deep interview with the manager of JED and then deep interview with the coordinator of JED in every village, and also deep interview with the tourist to know their motivation visit Pelaga Ecotourism Village. While also using literature study and documentation.

The result of this research show that in term geographic characteristic the visitor in Pelaga, Sibetan, and Tenganan Village is come from various country namely USA, Australia, Thailand, Japan, Germany, Canada, Netherland, England, France, Norway, Belgium, Philippines, Italy, Singapore, Malaysia, Cambodia, China, Poland, East Timor, Finland, Korea. In term sociodemographic characteristic the tourist who visit Pelaga and Sibetan dominated by man and in productive age, while in Tenganan is dominated by women and in older age. The whole tourist in three villages are work in private or public sector, and high educational background. Most of tourists who visit, have the motivation to know the culture in three villages.
\end{abstract}

Keywords: Tourist Characteristic, Tourist Motivation, Eco-tourism, Village Ecotourism Network.

\section{PENDAHULUAN}

Pariwisata

Bali mengalami pertumbuhan yang semakin meningkat dari tahun ke tahun, berdasarkan tabel diatas jumlah kunjungan wisatawan memiliki ratarata pertumbuhan sebesar $10,78 \%$ pertahun sejak tahun 2009 - 2014. Kenaikan jumlah kunjungan wisatawan tersebut membuktikan bahwa memang Bali memiliki potensi pariwisata yang semakin membaik.

Namun jika melihat Peraturan Daerah Provinsi Bali tentang tujuan pembangunan pariwisata yaitu dalam Peraturan Daerah
Provinsi Bali Nomor 2 Tahun 2012 tentang kepariwisataan budaya Bali disebutkan bahwa, tujuan dari pembangunan pariwisata adalah untuk meningkatkan kesejahteraan masyarakat Bali secara merata dan berkelanjutan; serta melestarikan lingkungan alam Bali sebagai basis penyangga kehidupan masyarakat dan kebudayaan Bali secara berkelanjutan." Tujuan ini belum sepenuhnya tercapai, sebab jumlah kunjungan wisatawan dan juga pembangunan pariwisata masih belum merata di setiap kabupaten. 
Jumlah kunjungan wisatawan selama lima tahun terakhir, paling banyak di Kabupaten Tabanan yaitu sebanyak 18.226.972 wisatawan, urutan kedua adalah Kabupaten Gianyar, yaitu sebanyak 7.861.511 dan kemudian yang ketiga Kabupaten Badung, yaitu sebanyak 5.293.631 wisatawan sedangkan yang paling sedikit adalah kabupaten Jembrana, yaitu hanya 526.564 wisatawan. Melalui perbandingan data jumlah kunjungan wisatawan antar kabupaten di atas terlihat dengan jelas adanya ketimpangan kunjungan wisatawan yang tidak merata di Bali. Salah satu penyebabnya adalah pembangunan tanpa adanya pemetaan yang jelas mengenai pasar wisatawan dan tanpa mempertimbangkan daya dukung alam, lingkungan, budaya sebagai produk yang ditawarkan dengan sistem pemasaran yang digunakan.

Sedangkan disisi lain, pembangunan pariwisata yang sangat mempertimbangkan lingkungan, alam serta kebudayaan adalah pariwisata minat khusus. Wisata minat khusus (Special Interest Tourism) merupakan bentuk kegiatan dengan wisatawan individu, kelompok atau rombongan kecil yang bertujuan untuk belajar dan berupaya mendapatkan pengalaman tentang suatu hal di daerah yang dikunjungi. Saat ini Pemerintahan Provinsi Bali sedang mengembangkan pariwisata minat khusus melalui program Bali Mandara jilid II, yaitu berupa program pengembangan desa wisata. Program ini dilakukan berdasarkan Peraturan Daerah No 16 Tahun 2009 tentang Rencana Tata Ruang Wilayah Provinsi Bali dimana dalam hal ini, pengembangan sektor pariwisata berlandaskan kebudayaan dan Agama Hindu yang berbasis pemberdayaan masyarakat. Dalam program tersebut ada 180 desa yang direncanakan dikembangkan oleh pemerintah menjadi desa wisata. Salah satu jenis dari pariwisata minat khusus yang dikembangkan adalah ekowisata. Ekowisata adalah bentuk industri pariwisata berbasis lingkungan yang memberikan dampak kecil bagi kerusakan lingkungan dan budaya lokal sekaligus menciptakan peluang kerja dan menambah pendapatan serta membantu kegiatan konservasi alam.

Pada Tahun 1999 sebuah yayasan yang bergerak di bidang lingkungan hidup dan pemberdayaan masyarakat melakukan pemetaan terhadap potensi-potensi desa yang ada di Bali. Berdasarkan hasil pemetaan tersebut di temukan empat desa yang memiliki potensi ekowisata, yaitu Desa Pelaga (Badung), Desa Sibetan (Karangasem), Desa Adat Tenganan (Karangasem), dan Desa Nusa Ceningan (Klungkung). Setelah melihat potensi tersebut, keempat desa ini bersamasama membentuk Jaringan Ekowisata Desa (JED). JED ini bertujuan untuk mewujudkan program ekowisata yang berbasis pada masyarakat dan lingkungan di keempat desa tersebut serta sebagai bentuk komitmen dari keempat kelompok masyarakat desa itu yang ingin menentukan masa depan dirinya sendiri, budaya dan lingkungannya.

Dalam proses pengembangan desa ekowisata yang dilakukan oleh JED ternyata sampai saat ini jumlah kunjungan wisatawan belum mencapai target yang telah ditentukan. Sebagai contoh,di salah satu desa yang menjadi lokasi penelitian yaitu Desa Pelaga target jumlah kunjungan yang telah ditentukan adalah sebanyak 10 wisatawan dalam sehari, yang artinya dalam setahun dapat mencapai 3600 wisatawan. Sampai saat ini jumlah kunjungan wisatawan yang datang ke desa Pelaga masih mencapai 200 wisatawan dalam satu tahun, jumlah kunjungan yang datang ke Desa Pelaga ini sangat timpang bila dibandingkan dengan jumlah wisatawan yang datang ke Bali yang mencapai 3.278.598 wisatawan pada Tahun 2013. Berdasarkan hal tersebut maka perlu dilakukan penelitian mengenai karakteristik dan motivasi dan wisatawan di desa-desa yang tergabung dalam JED. Dengan mengetahui karakteristik dan motivasi wisatawan yang berkunjung ke desadesa yang tergabung dalam JED , maka setiap destinasi akan dapat diupayakan untuk semakin sesuai ataupun bisa memenuhi kriteria motivasi wisatawan yang berkunjung sehingga dapat dilakukan upaya-upaya yang bisa meningkatkan jumlah kunjungan wisatawan

\section{METODE PENELITIAN}

Teknik pengambilan sampel dalam penelitian ini dengan cara pengambilan purposive sampling. Purposive sampling dibagi menjadi dua yaitu informan pangkal dan informan kunci. Informan pangkal dalam penelitian ini adalah Koordinator JED di setiap desa jaringan ekowisata, untuk mendapatkan informasi mengenai potensi yang dimiliki desa 
tersebut., sedangkan informan kunci adalah ketua Jaringan Ekowisata Desa (JED).

Selain purposive sampling, penelitian ini juga menggunakan accidental sampling yang di tujukan bagi wisatawan, tujuannya adalah untuk mendapat informasi mengenai motivasi wisatawan. Sampel akan diambil secara acak dalam artian wisatawan yang datang diambil secara acak untuk diwawancara.

Penelitian ini menggunakan analisis data deskriptif kualitatif. Proses analisis kualitatif ini menggunakan pengumpulan data melalui teknik wawancara, observasi dan dokumentasi. Kemudian dalam proses pengumpulan tersebut dilakukan proses reduksi, penyajian data, dan juga penarikan kesimpulan.

Dalam proses reduksi data, kegiatan yang dimaksud adalah proses pemilihan penyederhanaan, pengabstrakan, mengubah data-data kasar yang muncul dari catatancatatan tertulis dilapangan. Kegiatan reduksi data terjadi terus menerus selama penelitian atau selama pengumpulan data terjadi tahapan reduksi yaitu membuat ringkasan, menelusuri tema, menulis memo, penggolongan, pembuangan data yang tidak diperlukan. Dalam penelitian ini kegiatan reduksi dilakukan semenjak pengumpulan data yaitu hasil wawancara dengan manajer JED maupun dengan koordinator JED di setiap desa.

Alur kedua adalah penyajian data, yaitu dari sekumpulan informasi mengenai sejarah, karakterisitik, maupun motivisasi wisatawan akan disusun sebagai data untuk disajikan. Dalam alur yang terakhir yaitu kegiatan penarikan kesimpulan / verifikasi. Sesudah mendapatkan seluruh data, kemudian setelah dilakukan proses reduksi dan penyajian data maka dalam penelitian ini akan dicoba mengaitkan antara teori yang ada mengenai karakteristik dan motivasi wisatawan dengan data yang sudah dikumpulkan dan sudah melalui proses reduksi ,sehingga penarikan kesimpulan penelitian yang dilakukan tetap berdasarkan teori yang ada.

\section{HASIL DAN PEMBAHASAN \\ Karakteristik Wisatawan Berdasarkan Karakteristik Geografi}

Negara-negara asal wistawan yang pernah melakukan kunjungan ke desa ekowisata di Bali adalah : Amerika Serikat,
Australia, Thailand, Jepang, German, Canada, Belanda, Inggris, Perancis, Norwegia, Belgia, Filipina, Italia, Singapura, Malaysia, Kamboja, China,Polandia, Timorleste, Finlandia, Korea.

Setiap tahun kunjungan datang dari berbagai negara di seluruh dunia, namun dengan jumlah kunjungan yang tidak merata, negara-negara yang pernah memiliki jumlah kunjungan tertinggi namun pada tahun berikutnya mengalami jumlah penurunan kunjungan. Jumlah kunjungan terbanyak pada tahun 2009 berasal dari Negara Perancis dengan total kunjungan sebesar 28, dan pada tahun 2010 jumlah wisatawan terbanyak berasal dari Negara Perancis yaitu sebanyak 52 wisatawan, sedangkan pada tahun 2011 dan 2012 jumlah kunjungan wisatawan terbanyak adalah wisatawan domestik yaitu wisatawan Indonesia dengan jumlah kunjungan sebanyak 63 wisatawan, pada tahun 2011 dan 84 wisatawan pada tahun 2012 , kemudian pada tahun 2013 jumlah kumjungan wisatawan terbanyak berasal dari Negara Korea sebanyak 58 wisatawan. Berdasarkan data tersebut dapat dilihat terjadi pergeseran jumlah kunjungan wisatawan, pada tahun 2009 dan 2010 peminat ekowisata di Bali berasal dari Benua Eropa, namun dalam tahun terakhir wisatawan ekowisata lebih banyak berasal dari Benua Asia.

\section{Karakteristik Wisatawan Berdasarkan Karakterisitik Sosio-Demografi}

Jumlah wisatawan laki-laki lebih banyak dibandingkan wanita. Hal ini dipengaruhi oleh jenis kegiatan wisata ditawarkan adalah adventure, yaitu mengelilingi desa dan perkebunan milik masyarakat. Kegiatan ini membutuhkan stamina yang cukup, Sehingga wisatawan pria akan lebih tertarik dibanding wisatawan wanita. Jumlah kunjungan wisatawan berdasarkan karakteristik umur, terlihat wisatawan dengan usia antara 20 sampai 30 tahun merupakan wisatawan yang paling banyak menyukai jenis kegiatan ekowisata yaitu sebesar 17 orang $(23,9 \%)$ dari total 71 orang wisatawan pada tahun 2014. dan paling banyak kedua adalah wisatawan dengan usia antara 30 sampai 40 tahun sebesar 16 orang $(22,5 \%)$ dan wisatawan dengan usia diatas 10 sampai 20 tahun sebesar 15 orang $(21,1 \%)$.

Persentasi jumlah kunjungan berdasarkan usia di atas terlihat bahwa 
wisatawan yang paling banyak berkunjung adalah pada usia yang masih muda atau masih dalam usia produktif. Hal tersebut dapat disebabkan karena jenis kegiatan ekowista yang disuguhkan adalah berupa aktivitas tracking maupun cycling mengelilingi desa dan perkebunan milik warga untuk menikmati alam. Kegiatan-kegiatan tersebut membutuhkan tenaga yang cukup. Wisatawan dengan usia antara 17 sampai 30 tahun masih cukup bugar dan kuat untuk melakukan jenis wisata tersebut. Oleh sebab itu, wisatawan yang paling banyak mengunjungi desa ini adalah wisatawan yang masih dalam usia produktif.

Karakteristik wisatawan ekowisata yang berkunjung ke Bali jika dilihat dari tingkat pendidikannya merupakan lulusan universitas ataupun mahasiswa yang sedang duduk di bangku kuliah. Tingkat pendidikan tersebut sangat mempengaruhi tujuan dan juga motivasi perjalanan wisatawan. Destinasi yang mereka pilih bukan hanya sebagai tempat untuk berlibur melainkan juga sebagai tempat untuk mendapatkan pelajaran. Tingkat pendidikan yang lebih tinggi mempengaruhi cara pandang wisatawan terhadap budaya yang berbeda. Mereka akan mempelajari dan juga sangat mengapresiasi setiap perbedaan kebudayaan yang mereka temui. Di desa Sibetan misalnya, mereka mendapat kesempatan untuk belajar tentang budidaya salak, pembuatan wine dari salak dan pelajaran-pelajaran lain mengenai gaya hidup masyarakat yang mungkin mereka dapatkan. Jenis pekerjaan yang dimiliki wisatawan mempengaruhi tingkat penghasilan wisatawan sehingga hal itu mempengaruhi wisatawan dalam memilih jenis wisata yang akan dilakukan.

Berdasarkan perkerjaan wisatawan yang berkunjung dari total 71 wisatawan pada tahun 2014 hanya terdapat tiga jenis pekerjaan, yaitu wisatawan yang memiliki jenis pekerjaan di bidang swasta/publik sebesar 45 orang $(63,4 \%)$. Jenis pekerjaan swasta / publik yang dimaksud adalah pekerjaan sebagai karyawan di perusahaan maupun pemilik perusahaan itu sendiri. Jenis pekerjaan terdiri dari dosen, guru, staf kantor universitas, dan juga teknisi.

Kemudian sebesar 28,1\% wisatawan yang mengunjungi Desa Ekowisata Pelaga adalah mahasiswa yang sedang menempuh pendidikan sarjana maupun magister.
Mahasiswa memanfaatkan waktu liburan mereka, namun ada juga yang datang dalam masa kuliah dengan tujuan penelitian lapangan Wisatawan yang bekerja pada pemerintahan hanya sebanyak 6 orang atau sebesar 8,4\% pada tahun 2014 .

\section{Motivasi Wisatawan}

Untuk mengetahui motivasi kunjungan wisatawan ekowisata yang datang ke Bali, maka digunakan rekomendasi teori motivasi dari Robert Mac Intosh. Ada empat yang membentuk motivasi wisatawan dalam berkunjung yaitu physical, cultural, interpersonal, status dan prestige.

Mayoritas wisatawan ekowisata yang berkunjung ke Bali didorong oleh motivasi budaya atau cultural motivation. Sebanyak 50 orang wisatawan atau 70,4\% dari total jumlah 71 orang wisatawan ekowisata yang berkunjung. Mereka ingin mengetahui pola dan cara hidup masyarakat secara langsung. Di Desa Sibetan dan di Desa Pelaga misalnya wisatawan diijinkan untuk tinggal di rumahrumah masyarakat, sehingga wisatawan bisa secara langsung melihat merasakan budaya Desa Sibetan mulai dari bangun pagi sampai malam hari.

Di Desa Tenganan yang meskipun di desa ini wisatawan tidak diijinkan untuk menginap, namun banyak sekali yang bisa di pelajari wisatawan mengenai budaya Bali yang unik, sebab Desa Tenganan merupakan Bali aga (masyarakat Bali asli), sehingga budaya yang mereka miliki berbeda dengan desa lain yang ada di Bali. Tradisi megibung misalnya atau yang biasa disebut makan bersama dalam satu tempat makan. Megibung ini mempunyai makna untuk penyetaraan dan kebersamaan untuk menunjukkan bahwa di Desa Teganan Dauh Tukad tidak ada kasta dan penggolongan sosial. Wisatawan dapat menikmati secara langsung budaya tersebut. Apabila wisatawan datang pada waktu yang tepat, wisatawan juga dapat menyaksikan secara langsung proses perekrutan calon pemimpin desa yang sangat unik. Salah satunya melalui prosesi adat perang buah pisang yang di ikuti oleh teruna Desa Adat Tengana Dauh Tukad, yang tujuannya untuk mencari calon pemimipin dan calon wakil pemimpin. Pada tanggal yang ditentukan oleh budaya setempat juga digelar tradisi unik yaitu perang pandan yang dilakukan untuk menghormati Dewa Indra 
atau Dewa Perang. Tradisi ini sangat unik dimana dua pasang pemuda desa akan bertarung diatas panggung dan saling menyayat dengan menggunakan duri-duri pandan. Meskipun sayatan tersebut akan menimbulkan luka, namun mereka sudah memiliki obat antiseptik dari bahan umbiumbian yang akan diolesi pada semua luka hingga mengering dan sembuh dalam beberapa hari. Tradisi tetap dilakukan sebagai latihan perang rutin dan agar warga memiliki kondisi fisik serta mental yang kuat.

Wisatawan ekowisata lain yang berkunjung ke Bali didorong oleh motivasi fisik atau physical motivation yaitu untuk melepaskan kelelahan fisik sebanyak 21 orang wisatawan atau 29,6\%. Wisatawan yang didorong oleh motivasi ini menyebutkan mereka memilih kegiatan ekowisata untuk menikmati liburan dan melepaskan penat dari kesibukan kerja. Mereka memili ekowisata dikarenakan mereka ingin mengetahui dan melihat Bali yang sesungguhnya. Mereka juga menyebutkan bahwa mereka ingin benar-benar merasakan jenis wisata yang berbeda dengan yang ada ditempat asal mereka, karena mereka bisa menikmati keindahan alam Bali yang masih natural.

\section{SIMPULAN DAN SARAN}

\section{Simpulan}

1. Secara karakteristik geografi Negaranegara asal wistawan yang pernah melakukan kunjungan wisata ke Desa Pelaga, Desa Tenganan, dan Desa Kiadan adalah : Amerika Serikat, Australia, Thailand, Jepang, German, Canada, Belanda, Inggris, Perancis, Norwegia, Belgia, Filipina, Italia, Singapura, Malaysia, Kamboja, China,Polandia, Timorleste, Finlandia, Korea.

2. Secara Demografi wisatawan yang paling banyak berkunjung adalah wisatawan lakilaki sebesar 52,2\% dan pada usia antara 20 sampai 30 yaitu sebesar 23,9\%. Wisatawan ekowisata yang berkunjung ke Bali jika dilihat dari tingkat pendidikannya merupakan lulusan universitas ataupun mahasiswa yang sedang duduk di bangku kuliah. Tingkat pendidikan tersebut sangat mempengaruhi tujuan dan juga motivasi perjalanan wisatawan. Destinasi yang mereka pilih bukan hanya sebagai tempat untuk berlibur melainkan juga sebagai tempat untuk mendapatkan pelajaran. Berdasarkan perkerjaan wisatawan yang berkunjung dari total 71 wisatawan pada tahun 2014 hanya terdapat tiga jenis pekerjaan, yaitu wisatawan yang memiliki jenis pekerjaan di bidang swasta/publik sebesar 45 orang $(63,4 \%)$, kemudian sebesar 20\% wisatawan yang mengunjungi Desa Ekowisata Pelaga adalah mahasiswa yang sedang menempuh pendidikan dan wisatawan yang bekerja pada pemerintahan hanya sebesar $8,4 \%$ pada tahun 2014

3. Mayoritas wisatawan ekowisata yang berkunjung ke Bali didorong oleh motivasi budaya atau cultural motivation. Sebanyak 50 orang wisatawan atau 70,4\% dari total jumlah 71 orang wisatawan ekowisata yang berkunjung. Mereka ingin mengetahui pola dan cara hidup masyarakat secara langsung. Wisatawan ekowisata lain yang berkunjung ke Bali didorong oleh motivasi fisik atau physical motivation yaitu untuk melepaskan kelelahan fisik yang disebabkan oleh pekerjaan sebanyak 21 orang wisatawan atau $29,6 \%$.

\section{Saran}

1. Menjadikan karakteristik dan motivasi wisatawan sebagai bahan pertimbangan bagi perusahan, lembaga maupun institusi yang ingin mengembangkan desa ekowisata.

2. Meningkatkan kegiatan promosi khususnya kepada JED, dengan mempertimbangkan karakteristik dan motivasi wisatawan. Sehingga jumlah kunjungan wisatawan dapat meningkat.

3. Menjadikan hasil penelitian ini sebagai bahan acuan untuk dilanjutkan oleh mahasiswa pada penelitian selanjutnya.

\section{DAFTAR PUSTAKA}

Damanik, A. (2006). Perencanaan Ekowisata Dari Teori Ke Aplikasi .Yogyakarta : Penerbit Andi.

Peraturan Daerah Provinsi Bali (2012).

Sugiono. (2009). Metode Penelitian Pendekatan Kuantitatif, Kualitatif dan $R \& D$. Bandung: Alfa Beta.

Suwena I Ketut, I. G. (2010). Pengetahuan Dasar Ilmu Pariwisata. Denpasar: Udayana University Press. 